\title{
THE EFFECT OF ORGANIC PEROXIDES ON THE CURING BEHAVIOR OF EPDM ISOLATION MEDIUM VOLTAGE CABLES
}

Jelena Radosavljević ${ }^{\star}$, Ljubiša Nikolić

University of Niš, Faculty of Technology, Leskovac, Serbia

This work describes the influence of the concentration and type of peroxides on cure efficiency of various types of EPDMs (ethylene propylene diene monomer (M-class) rubber), [1][2][10]) with the various content of ethylene characterized by a wide range of applications. Rheology characteristics was investigated using the Monsanto Rheometer in the temperature range between 180 and $200{ }^{\circ} \mathrm{C}$, with the data provided every $10{ }^{\circ} \mathrm{C}$. Mechanical properties (tensile strenght and elongation at break) was investigated using tensile tests according to standard ASTM D-412. The obtained results showed that peroxide (2.5-Dimethyl-2.5-Di (tert-butylperoxy) hexane (DTBPH) with the concentration of $7.5 \mathrm{phr}$ (cure time $1.5 \mathrm{~min}$ ) had a higher performance at the temperatures of 180 to $190^{\circ} \mathrm{C}$. At the higher peroxide level, there is the increase in the amount of residual peroxide, as well as the possibility of the formation of clusters due to the nonhomogeneous distribution of crosslinks. Peroxide cured EPDM with $45 \mathrm{wt} \%$ of the ethylene content gives the most effective mechanical properties for medium voltage cables. It is to be noted that 100 for Dicumyl peroxide (DCP), Di (tert-butylperoxyisopropyl) benzene (DTBPIB), and (2.5-Dimethyl-2.5-Di (tert-butylperoxy) hexane (DTBPH) accounts for an average of 2 to 3 half-lives.
(ORIGINAL SCIENTIFIC PAPER) UDC 678.7:66.095.26:665.94

Keywords: crosslinking, kinetics, EPDM, organic peroxide, rheology

\section{Introduction}

One of the most diffused materials utilized for electric cable insulation is EPDM with the low unsaturation level and suitable dielectric properties, good aging resistance and good mechanical strength [1]. Rubber industry usually performs the curing characterization that will affect the processing physical, mechanical and dynamic properties. The study of the process of cure of EPDM rubbers in moving die rheometer (MDR) was studied by Rosca and Verghaud [2]. The reported cure time for a particular system is often inconsistent, this behavior of cure time results either in cure or excess residual peroxide (under-cured) in vulcanizates, both causing a reduction in mechanical properties. A wide range of peroxides for crosslinking of rubber is available on the market. Some of typically used peroxides are shown in Figure 1. Normally, relatively stable peroxides are selected for rubber vulcanisation, since they should be stable at the storage temperature and also compounding temperature, which can be rather high. However, they should be labile enough to quickly yield the radical species at the vulcanisation temperature, yet providing the proper scorch safety. The reactivity of peroxide is mainly determined by its molecular structure [3].<smiles>CC(C)(C)OOC(C)(C)CCC(C)(C)OOC(C)(C)C</smiles>

2,5-Dimethyl-2,5-di(tert-butylperoxy)hexane (DTBPH)<smiles>CC(C)(OOC(C)(C)c1ccccc1)c1ccccc1</smiles>

Dicumyl peroxide (DCP)<smiles>CC(C)(C)OOC(C)(C)c1ccc(C(C)(C)OOC(C)(C)C)cc1</smiles>

Di(tert-butylperoxyisopropyl)benzene (DTBPIB)

Figure 1. Example of commonly used peroxides for rubber crosslinking

Several authors agree with the fact that the following are very important factors to take into account in order to select a proper peroxide [3, 4, 5, 6, 7, 8] : Harmless decomposition products, the effect of additives on the

\footnotetext{
*Author address: Jelena Radosavljević, Faculty of Technology, University of Niš,

Bulevar Oslobođenja 124, 16000 Leskovac, Serbia

E-mail: jefimijajelena@gmail.com

The manuscript received: December, 28, 2017.

Paper accepted: March, 20, 2018.
} 
efficiency on a stability, vulnerability to side reactions that lower the efficency, non-volatility: to prevent loss during compounding and mixing, a possible generation of odour, safety: it should be non irritant and non-toxic (safe at the storage temperature, the processing temperature and at the increased production of decomposition products. A very important factor considered in peroxide selection is the nature of the radicals formed by its decomposition. Depending on the reactivity of these radicals, subsequent rearranging reactions take place leading to new radical species. These new radicals are sometimes reactive, but in other cases loose reactivity compared to the initial radical, and that will negatively reflect in the peroxide efficiency. For instance, when using DCP, one of the most used crosslinking peroxides are decomposition methyl radicals, see Figure 2 [6]. These radicals are still very reactive, and at the same time they are less sterically hindered than the initial cumyloxy radicals. Therefore, they will further easily react and provide good crosslink efficiency. The best radicals for peroxide crosslinking are those which are good abstractors, like for instance methyl and cumyloxy radicals, and poor in addition to double bonds. Figures 2-4 present main mechanisms of each peroxide to generate crosslinking.

For DCP, the actual crosslinking occurs by 2-phenylpropanoxy radicals and methyl radicals (Figure 2 ) while with DTBPIB decomposition products which can abstract hydrogen atoms they are tert butoxy, methyl and di-(hydrohy-i-propyl) benzen radicals shown in Figure 3.

The rate at which peroxide crosslinking takes place is dependent on the decomposition temperature of the selected peroxide, because the initial and rate determing step in the crosslinking process is the first order formation of free alkoxy radicals. A proper peroxide should therefore be selected on the basis of its decomposition rate at the approximate processing temperature [9]. The aromatic nature of peroxides is related to the decomposition temperature of the peroxides being lower with the higher aromatic content.

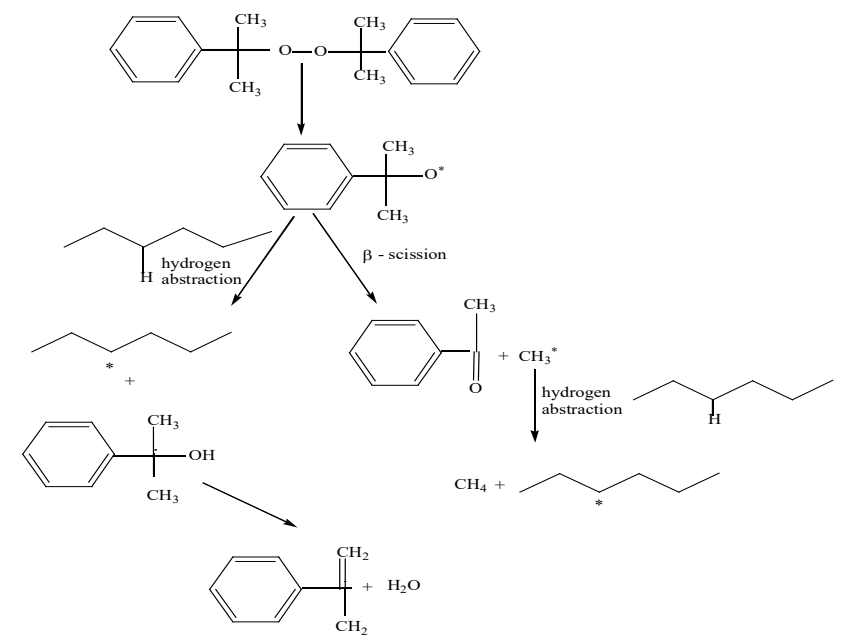

Figure 2. Decomposition mechanism of Dicumyl peroxide (DCP)
The first step of crosslinking is the homolytic scission of DCP molecules to form two alkoxy radicals. The kinetic parameters of this reaction depend solely on temperature and the concetration of DCP and are independent of any other species in the system. In the next step, the ß cleavage of cumyloxy radicals leads to the formation of acetophenone molecules. Acetophenone is volatile and leaves the system during crosslinking. The side products of the acetophenone formation is methyl radical which, based on the proposed mechanism, holds the same kinetic parameters as acetophenone. Cumyloxy radical can also directly attack hidrocarbon chains and abstract a hydrogen atom from a cumylalcohol molecule and macroradicals. Methyl radicals resulting from ß-scission of cumyloxy can whether abstract a hydrogen atom to form methane molecule and a macroradical, or combine with another methyl radical to form an ethane molecule. These two molecules are highly volatile and can easly evaporate out of the system. The formation ratio between these two products was determined, but regarding the low concetration of methyl radical it is easy to conclude that the concetration of methane would be higher than of ethan. The consumption of ENB double bond is the result of a radical attack of previously formed macroradicals. The addition of macroradical onto an ENB double bond creates a macroradical and a crosslink. This latter can also be created by the combination of secondary radicals formed from ethylene units. Therefore, the total number of crosslinks can be calculated by summing up these two contributions.A kinetic approach for the lifetime determination of DCP is possible considering the first-order decomposition reaction of DCP. In the literature, the activation energy equal to $140 \mathrm{KJ}_{\mathrm{mol}}{ }^{-1}$ and a pre-exponential factor equal to $1.85 \times 1014$ is found [9]. With these data, we obtain a half-life of 2 minutes for DCP at $170^{\circ} \mathrm{C}$. Consequently, the conversion of DCP after 15 minutes at $170{ }^{\circ} \mathrm{C}$ is higher than $99 \%$. It is important to precise that the residual value is not capable of giving any quantitative information about the concentration of consumed residual peroxide, and reveals only the time needed for the total consumption of DCP molecules.

The total crosslinking enthalpy remains constant per mole of peroxide for the concentrations inferior to $10 \mathrm{phr}$. Beyond this concentration, the total enthalpy per mole of peroxide decreases. This deviation has been previously reported in the work of Schwartz, where it was shown that deviation occurs for butyl rubber and nitrile butadiene rubber for the concentrations above $5 \mathrm{phr}$ of peroxide [10]. The deviation from linearity beyond $10 \mathrm{phr}$ of DCP is related to dispersion state of peroxide in the matrix. In fact, at low concentrations the peroxide molecules are homogeneously dispersed among polymer chains. However, as the concentration increases, the DCP molecules get closer and form clusters. General characteristics of peroxides are given in Table 1. 


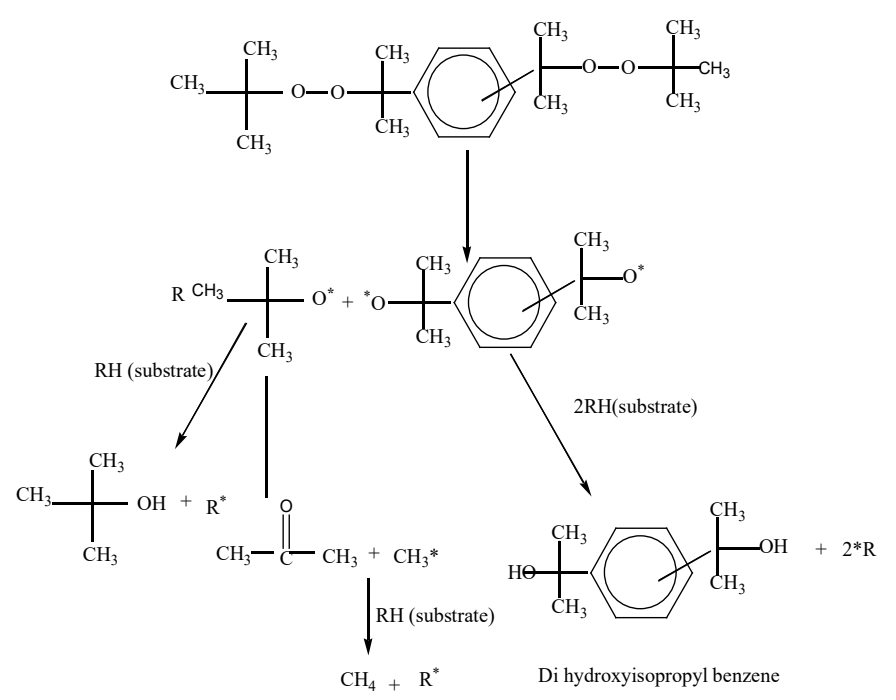

Figure 3 Decomposition mechanism of Di (tert-butylperoxyisopropyl) benzene (DTBPIB)

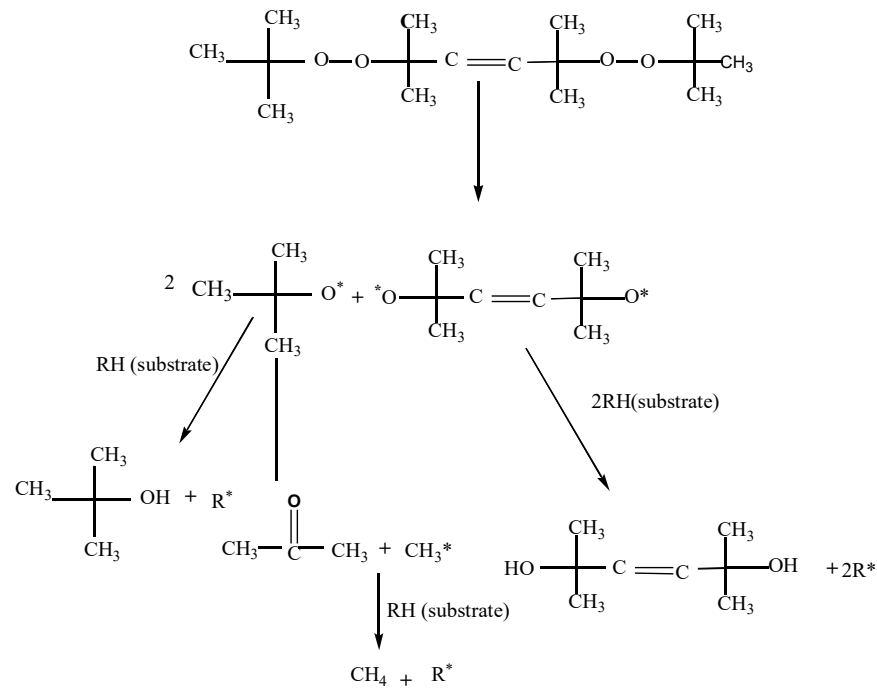

Figure 4 Decomposition mechanism of (2.5-Dimethyl-2.5-Di (tert-butylperoxy) hexane (DTBPH)

Table 1. General characteristics of peroxides (investigated) [11]

\begin{tabular}{|c|c|c|c|c|}
\hline Peroxides & $\mathbf{M}_{\mathrm{w}}$ & $\begin{array}{l}\text { Temperature }\left({ }^{\circ} \mathrm{C}\right) \\
\mathbf{t}_{1 / 2}=1 \min \end{array}$ & $\begin{array}{l}\text { Typical } \\
\text { Crosslinking } \\
\text { Temperature }\left({ }^{\circ} \mathrm{C}\right)\end{array}$ & $\begin{array}{l}\text { Crosslink } \\
\text { efficiency* } \\
(\%)\end{array}$ \\
\hline DTBPH & 290 & 183 & 170 & \\
\hline DTBPIB & 338 & 185 & 170 & 52 \\
\hline DCP & 270 & 189 & 160 & 50 \\
\hline
\end{tabular}

${ }^{*}$ Crosslink eficiency of pure grages

The rank of cure rates for these peroxides follows: DTBPH $<$ DCP $<$ DTBPIB [11]. The typical crosslinking temperature is the temperature at which about $90 \%$ of the crosslinking activity occurs within 12 min [5].

Vulcanization Kinetics

The general equation for the kinetics of the first-order chemical reaction is:

$$
\ln (a-x)=k t+\ln a
$$

where, (a) -initial peroxide concentration, [phr]

$(x)$-reacted quantity at time $t,[p h r]$

(k) -first-order reaction rate constant

for typical peroxides $\left(t_{1 / 2}\right)$ drops to about $1 / 3$ of its value for each $10^{\circ} \mathrm{C}$ increase of the temperature. The half-life is obtained as:

$t_{1 / 2}=\ln 2 / k$

The larger the value of the first-order rate constant $k$, the faster the reaction.

\section{Determination of Curing Rate}

Cure time $t c_{90}$ and $t c_{10}$ and cure rate index were calculated following equations (3) and (4) respectively:

$t c_{x}=(x / 100)\left(M_{H}-M_{L}\right)+M_{L}$

where, $\left(M_{L}\right)$ - minimum torque [d.Nm],

$\left(M_{H}\right)$ - maximum torque [d.Nm],

$(x)$ - present state of cure [\%],

$\left(t c_{x}\right)$ - time to a given percent $(x)$ state to produce torque [min.]

High cure rate mens fast vulcanisation. The best processing conditions are achieved when $t s_{2}$ (scorch time) has a high value.

The scorch time $t s_{2}$ is taken at the time to reach $2 \%$ of the delta torque above minimum [12]. The increase in torque may take place very rapidly. If this occurs the partially crosslinked polymer cannot properly flow anymore, it is called premature scorch and is related to low $t s_{2}$ values. Also, the amount of residual peroxide can be calculated theoretically from the equation (5):

$$
((a-x) / a) \times 100
$$

where, $(a)$ - is the initial concentration of peroxide $\left(M_{H}-M_{L}\right)$ $(x)$ - reacted quantity of peroxide at time $t\left(M_{t}-M_{L}\right)$

\section{Experimental}

Materials and Method

EPDM for the study was Keltan 2470 (ethylene content $75 \mathrm{wt} \%$ ), Keltan 2450 (ethylene content $45 \mathrm{wt} \%$ ) and Keltan 5469Q (ethylene content 59wt \%) from Lanxess Bayer AG, Cologne, Germany. Peroxides from this study were Perkadox BC (Dicumyl peroxide (DCP), Perkadox 14/40 (Di (tert-butylperoxyisopropyl) benzene (DTBPIB)) and Trigonox 29/40 (2.5-Dimethyl-2.5-Di (tert-butylperoxy) hexane(DTBPH)) from Akzo Nobel N.V Amsterdam, the Netherlands. Besides EPDM and the peroxide, the present invention consists of other compounds such as: zinc oxide (IsoQure ZnO $25 \mathrm{CC}$ ) (ZnO coating min. 93\%) 
supplied by Isochem Kautschuk-Gmbh (Frankfurt), medium particle size calcined clay for anti blocking (Polestar 200 R) supplied by Imerys minerals, Cornwall (England) and Silane DSC supplied by Hexpol Compounding, Eupen (Belgium), antioxidant Vulkanox MB (4,5-Methylbenzimidazole-2-thiol) and cross linking activator for peroxide curing Rhenofit TAC/S (70 \% of triallyl cyanurate and $30 \%$ of silica) supplied by Lanxess Bayer AG, Cologne (Germany).

\section{Preparation of compounds}

The formulation used is given in Tables 2, 3 and 4. At the beginning, the weighted amount of EPDM was fed into the laboratory mixer at $50^{\circ} \mathrm{C}-60^{\circ} \mathrm{C}$ (Francis Shaw MK3, Manchester, England). Then $\mathrm{ZnO}$ powder with Vulkanox MB, Polestar 200 R, silane DSC and TAC/S (70\%) were added to the compound and the milling process continued for $10 \mathrm{~min}$. The curing agent peroxide was subsequently added to the mixture and the whole formulation was milled for additional $5 \mathrm{~min}$. To prepare the samples for further investigations, the resultant compounds were prepared on a two-roll mixing mill Berstroff, Hamburg as per ASTM D 3162-07. Determination of Mechanical Properties

Mechanical properties: tensile strength and elongation at break were determined using dumbbell-shaped specimens and measured according to ASTMD 412 by the testing machine OTTO Wolpert EZR-30, Germany. After preparing in a two-roll mixing mill, test specimens were pressed at $175^{\circ} \mathrm{C}$ for 20 minutes by the press Burkle Robert model LA 100, Germany and were cut from plates $150 \mathrm{~mm} \times 150 \mathrm{~mm} \times 2 \mathrm{~mm}$ by means of an automatic punching die.

Crosslinking Characteristic Measurement

The crosslinking characteristics were measured by Monsanto Moving Die Rheometer (MDR 2000 model, Alpha Technologies, USA) according to the test method ASTMD 5289-97.

About $4 \mathrm{~g}$ samples of the respective compounds were tested at the temperatures ranging from $180^{\circ} \mathrm{C}$ to $200^{\circ} \mathrm{C}$ with the measuring time of $15 \mathrm{~min}$.

Table 2. Formulation of mixes with Perkadox BC

\begin{tabular}{|c|c|c|c|c|c|c|c|c|c|}
\hline & $A_{1}$ & $\mathrm{~B}_{1}$ & $\mathrm{C}_{1}$ & $\mathrm{D}_{1}$ & $\mathrm{E}_{1}$ & $\mathrm{~F}_{1}$ & $\mathrm{G}_{1}$ & $I_{1}$ & $J_{1}$ \\
\hline Formulation & \multicolumn{3}{|c|}{ Keltan 2470} & \multicolumn{3}{|c|}{ Keltan 5469 Q } & \multicolumn{3}{|c|}{ Keltan 2450} \\
\hline EPDM, phr ${ }^{*}$ & 100 & 100 & 100 & 100 & 100 & 100 & 100 & 100 & 100 \\
\hline $\mathrm{DCP}, \mathrm{phr}$ & 7.5 & 10 & 12.5 & 7.5 & 10 & 12.5 & 7.5 & 10 & 12.5 \\
\hline $\begin{array}{l}\text { Ethylene content } \\
\text { in EPDM, wt \% }\end{array}$ & 75 & 75 & 75 & 59 & 59 & 59 & 45 & 45 & 45 \\
\hline Zinc oxide, phr & 5 & 5 & 5 & 5 & 5 & 5 & 5 & 15 & 15 \\
\hline Vulkanox MB, phr & 2 & 2 & 2 & 2 & 2 & 2 & 2 & 2 & 2 \\
\hline $\begin{array}{l}\text { Polestar } 200 \mathrm{R}, \\
\mathrm{phr}\end{array}$ & 100 & 100 & 100 & 100 & 100 & 100 & 100 & 100 & 100 \\
\hline Silane DSC, phr & 1.5 & 1.5 & 1.5 & 1.5 & 1.5 & 1.5 & 1.5 & 1.5 & 1.5 \\
\hline TAC/S (70\%), phr & 1.5 & 1.5 & 1.5 & 1.5 & 1.5 & 1.5 & 1.5 & 1.5 & 1.5 \\
\hline
\end{tabular}

" phr- parts per hundred
Table 3. Formulation of mixes with Perkadox $14 / 40$

\begin{tabular}{|c|c|c|c|c|c|c|c|c|c|}
\hline \multirow[b]{2}{*}{ Formulation } & $\mathrm{A}_{2}$ & $\mathrm{~B}_{2}$ & $\mathrm{C}_{2}$ & $\mathrm{D}_{2}$ & $\mathrm{E}_{2}$ & $\mathrm{~F}_{2}$ & $\mathrm{G}_{2}$ & $\mathrm{I}_{2}$ & $\mathrm{~J}_{2}$ \\
\hline & \multicolumn{3}{|c|}{ Keltan 2470} & \multicolumn{3}{|c|}{ Keltan 5469 Q } & \multicolumn{3}{|c|}{ Keltan 2450} \\
\hline EPDM, $\mathrm{phr}^{*}$ & 100 & 100 & 100 & 10 & 10 & 100 & 100 & 100 & 100 \\
\hline DTBPIB, phr & 7.5 & 10 & 12. & 7.5 & 10 & 12. & 7.5 & 10 & 12. \\
\hline $\begin{array}{l}\text { Ethylene } \\
\text { content in } \\
\text { EPDM, wt \% }\end{array}$ & 75 & 75 & 75 & 59 & 59 & 59 & 45 & 45 & 45 \\
\hline Zinc oxide, phr & 5 & 5 & 5 & 5 & 5 & 5 & 5 & 15 & 15 \\
\hline $\begin{array}{l}\text { Vulkanox MB, } \\
\text { phr }\end{array}$ & 2 & 2 & 2 & 2 & 2 & 2 & 2 & 2 & 2 \\
\hline $\begin{array}{l}\text { Polestar } 200 \mathrm{R} \text {, } \\
\text { phr }\end{array}$ & 100 & 100 & 100 & 1 & 1 & 100 & 100 & 100 & 100 \\
\hline $\begin{array}{l}\text { Silane DSC, } \\
\text { phr }\end{array}$ & 1.5 & 1.5 & 1.5 & 1.5 & 1.5 & 1.5 & 1.5 & 1.5 & 1.5 \\
\hline $\begin{array}{l}\text { TAC/S }(70 \%), \\
\text { phr }\end{array}$ & 1.5 & 1.5 & 1.5 & 1.5 & 1.5 & 1.5 & 1.5 & 1.5 & 1.5 \\
\hline
\end{tabular}

Table 4. Formulation of mixes with Trigonox 29/40

\begin{tabular}{|c|c|c|c|c|c|c|c|}
\hline & $\mathrm{A}_{3}$ & $\mathrm{D}_{3}$ & $\mathrm{E}_{3}$ & $\mathrm{~F}_{3}$ & $\mathrm{G}_{3}$ & $I_{3}$ & $J_{3}$ \\
\hline Formulation & $\begin{array}{l}\text { Keltan } \\
2470\end{array}$ & \multicolumn{3}{|c|}{ Keltan 5469 Q } & \multicolumn{3}{|c|}{ Keltan 2450} \\
\hline EPDM, phr & 100 & 100 & 100 & 100 & 100 & 100 & 100 \\
\hline DTBPH, phr & 7.5 & 7.5 & 10 & 12.5 & 7.5 & 10 & 12.5 \\
\hline $\begin{array}{l}\text { Ethylene content } \\
\text { in EPDM, wt \% }\end{array}$ & 75 & 59 & 59 & 59 & 45 & 45 & 45 \\
\hline Zinc oxide, phr & 5 & 5 & 5 & 5 & 5 & 15 & 15 \\
\hline Vulkanox MB, phr & 2 & 2 & 2 & 2 & 2 & 2 & 2 \\
\hline $\begin{array}{l}\text { Polestar } 200 \mathrm{R} \text {, } \\
\text { phr }\end{array}$ & 100 & 100 & 100 & 100 & 100 & 100 & 100 \\
\hline Silane DSC, phr & 1.5 & 1.5 & 1.5 & 1.5 & 1.5 & 1.5 & 1.5 \\
\hline TAC/S (70\%), phr & 1.5 & 1.5 & 1.5 & 1.5 & 1.5 & 1.5 & 1.5 \\
\hline
\end{tabular}

\section{Results and discussion}

The experimental cure curves of various peroxides used for the vulcanization of EPDM are presented in Figure 5. Reographs were recorded at $180^{\circ} \mathrm{C}, 190{ }^{\circ} \mathrm{C}$ and $200{ }^{\circ} \mathrm{C}$.

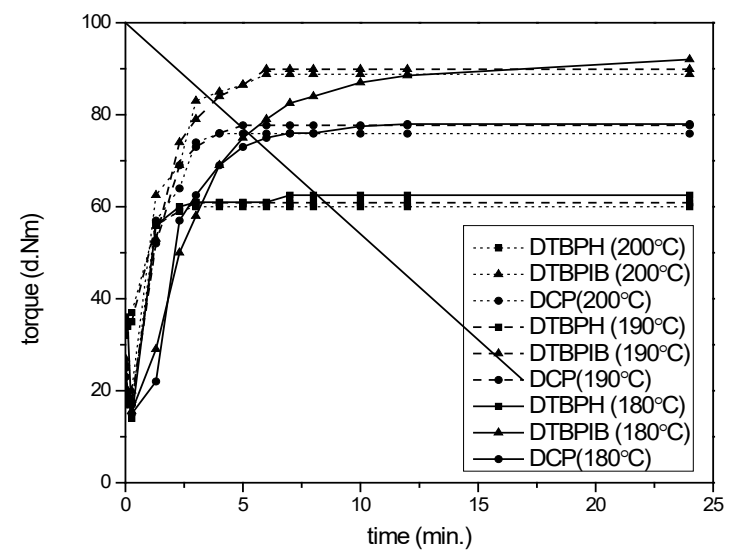

Figure 5.Rheometric curves of DCP cured EPDM at $180^{\circ} \mathrm{C}$, $190{ }^{\circ} \mathrm{C}, 200{ }^{\circ} \mathrm{C} \operatorname{mix} A_{1}, A_{2}, A_{3}$ 
According to the results presented in Figure 5, it can be seen that as the temperature increases, there is a non-significant increase in torque. Hence, the maximum torque depends on the temerature with the temperatures lower than $180^{\circ} \mathrm{C}$, where the rate of cure increases with the temperature increase, which leads to a high torque [13]. At $180{ }^{\circ} \mathrm{C}$, the optimum cure is reached, and it would take a minimum $11 \mathrm{~min}$. to complete the consumption of the DCP in the vulcanizate. The curve (at $180^{\circ} \mathrm{C}$ ) converges to a point and at $190^{\circ} \mathrm{C},\left(t_{100}\right)$ remains almost constant. At $200{ }^{\circ} \mathrm{C}$, the role of decomposition of peroxides is high and it is consumed in a limited time, hence the lower $t_{100}$ value. The cure parameter drawn from rheographs is given in Tables 5, 6 and 7 .

Table 5. Rheometric properties of vulcanizates (mix $\mathrm{A}_{1}, 7.5 \mathrm{phr}$ DCP loading)

\begin{tabular}{ccccccc}
\hline $\begin{array}{c}\text { Temperature } \\
{ }^{\circ} \mathrm{C}\end{array}$ & $\begin{array}{c}M_{H} \\
\text { d.Nm }\end{array}$ & $\begin{array}{c}M_{H}-M_{L} \\
\text { d.Nm }\end{array}$ & $\begin{array}{c}t_{90} \\
\text { min }\end{array}$ & $\begin{array}{c}t_{95} \\
\text { min }\end{array}$ & $\begin{array}{c}t_{100} \\
\text { min }\end{array}$ & $\begin{array}{c}t s_{2} \\
\text { min }\end{array}$ \\
\hline 180 & 78.0 & 62.5 & 4.27 & 5.30 & 11.0 & 0.8 \\
190 & 77.7 & 61.8 & 2.48 & 3.12 & 5.02 & 0.5 \\
200 & 75.9 & 60.4 & 1.48 & 2.09 & 3.03 & 0.5 \\
\hline
\end{tabular}

Table 6. Rheometric properties of vulcanizates (mix A2, $7.5 \mathrm{phr}$ DTBPIB loading)

\begin{tabular}{ccccccc}
\hline $\begin{array}{c}\text { Temperature } \\
{ }^{\circ} \mathrm{C}\end{array}$ & $\begin{array}{c}M_{H} \\
\text { d.Nm }\end{array}$ & $\begin{array}{c}M_{H}-M_{L} \\
\text { d.Nm }\end{array}$ & $\begin{array}{c}t_{90} \\
\text { min }\end{array}$ & $\begin{array}{c}t_{95} \\
\text { min }\end{array}$ & $\begin{array}{c}\mathrm{t}_{100} \\
\text { min }\end{array}$ & $\begin{array}{c}t s_{2} \\
\text { min }\end{array}$ \\
\hline 180 & 92.0 & 77.1 & 8.12 & 14.0 & 24.0 & 0.8 \\
190 & 89.9 & 72.4 & 3.36 & 4.45 & 8.30 & 0.6 \\
200 & 88.8 & 70.3 & 2.18 & 3.03 & 4.48 & 0.5 \\
\hline
\end{tabular}

Table 7. Rheometric properties of vulcanizates (mix $\mathrm{A}_{3}, 7.5 \mathrm{phr}$ DTBPH loading)

\begin{tabular}{ccccccc}
\hline $\begin{array}{c}\text { Temperature } \\
{ }^{\circ} \mathrm{C}\end{array}$ & $\begin{array}{c}M_{H} \\
\text { d.Nm }\end{array}$ & $\begin{array}{c}M_{H}-M_{L} \\
\text { d.Nm }\end{array}$ & $\begin{array}{c}t_{90} \\
\text { min }\end{array}$ & $\begin{array}{c}t_{95} \\
\text { min }\end{array}$ & $\begin{array}{c}t_{100} \\
\text { min }\end{array}$ & $\begin{array}{c}t s_{2} \\
\text { min }\end{array}$ \\
\hline 180 & 60.9 & 27.0 & 2.48 & 3.30 & 10.0 & 0.9 \\
190 & 62.5 & 28.6 & 1.54 & 3.30 & 4.39 & 0.5 \\
200 & 60.0 & 25.4 & 1.06 & 1.12 & 2.30 & 0.4 \\
\hline
\end{tabular}

According to the results presented in Tables 5, 6 and 7 , optimum cure times of peroxides $t_{90}$ at the temperature $190{ }^{\circ} \mathrm{C}$ has the highest influence on the curing efficiency. The experimental cure curves of various peroxides used for the vulcanization of EPDM are presented in Figure 6 . It can be seen from rheometer curves that the torque dramatically increases and reaches the equilibrium state within 2.48 to $3 \mathrm{~min}$. The highest influence has been noted at peroxide DTBPH with the lowest value of $t_{90}$ for EPDM. Thus, peroxide DTBPH gained the fastest and complete curing reaction. This parameter is used to describe the ability of peroxide to quickly decompose and generate free radicals. Compounds with different concentrations of peroxides are cured at $180{ }^{\circ} \mathrm{C}$ for 15 min., as it is shown in Figure 6. At the start of curing, there are non-significant changes in torque differences at peroxides DCP, DTBPIB rheometric curves, at vari- ous concentrations ( $7.5 \mathrm{phr}, 10 \mathrm{phr}$ and $12.5 \mathrm{phr}$ ) (Figure 6). After $1 \mathrm{~min}$. of vulcanization, the torque of peroxide DTBPH at all concentrations significantly increased reached an optimum cure. Peroxides DCP and DTBPIB reached maximum torque at the concentration of 12.5 phr and peroxide DTBPH has maximum torque at the concentration of $10 \mathrm{phr}$. According to the results presented in Figure 6, there are non-significant differences between the values of maximum torque at other concentrations of peroxides. These concentrations at which the maximum torque is reached may generate an excess of radicals for the crosslinking reaction much more than in other concentrations. In Figure 7, the effect of a different content of ethylene in EPDM with the peroxide concentration (7.5 phr) on the curing behavior of EPDM is shown. The results indicate that EPDM with peroxide DTBPIB applied in the concentration of (7.5 phr) and with the ethylene content of $59 \%$, can be cured faster than in other blends, $M_{H}$ was much higher than in the concentration (12.5 phr) (Figure 6).

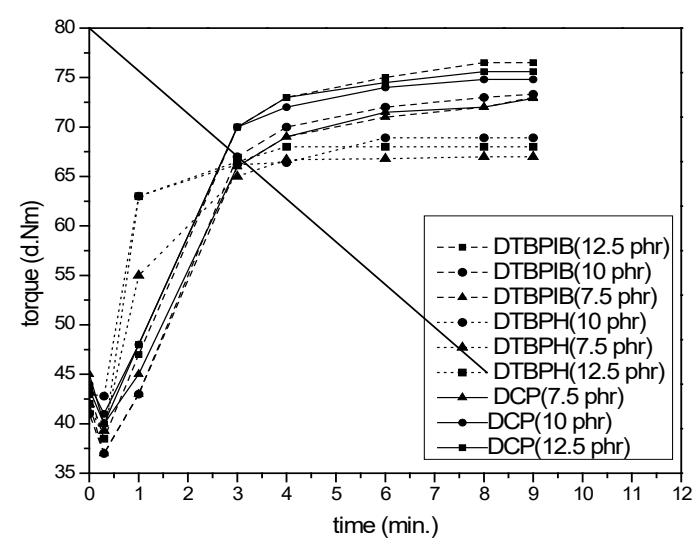

Figure 6. Rheometric curves of cured EPDM mix $D_{1}, E_{1}, F_{1}$, $B_{3}, E_{3}, F_{3}, D_{2}, E_{2}, F_{2}$ with various concentrations and types of peroxides at $180{ }^{\circ} \mathrm{C}$

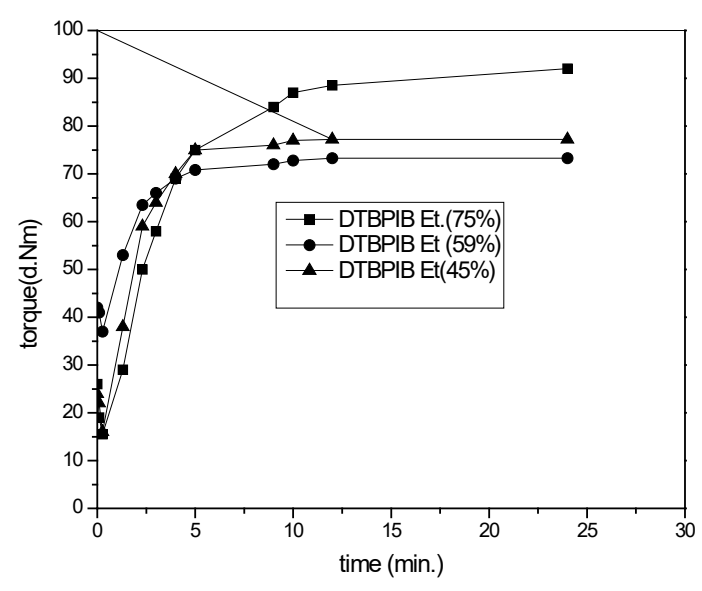

Figure 7. Rheometric curves of cured EPDM mix $A_{2}, D_{2}, G_{2}$ at $180^{\circ} \mathrm{C}$, with various contents of ethylene 


\section{Vulcanization kinetics}

As it can be seen in Figure 8, the reaction of crosslinking of EPDM with peroxide follows the first-order kinetics at all temperatures. The value of the rate constant can be derived from a relative measure of the reactant concentration with time. The change of the moment of crosslinking with the time is directly proportional to the density of the network. The linear dependence of the In $(\mathrm{M} \infty-\mathrm{Mt})$ function from the time of crosslinking indicates that the overall EPDM network reaction follows the firstorder kinetics. The rate of the EPDM networking reaction rate can be determined from the slope of this linear dependence. With increasing the temperature, the chemical reaction rate constant increases (Table 8 and 10).

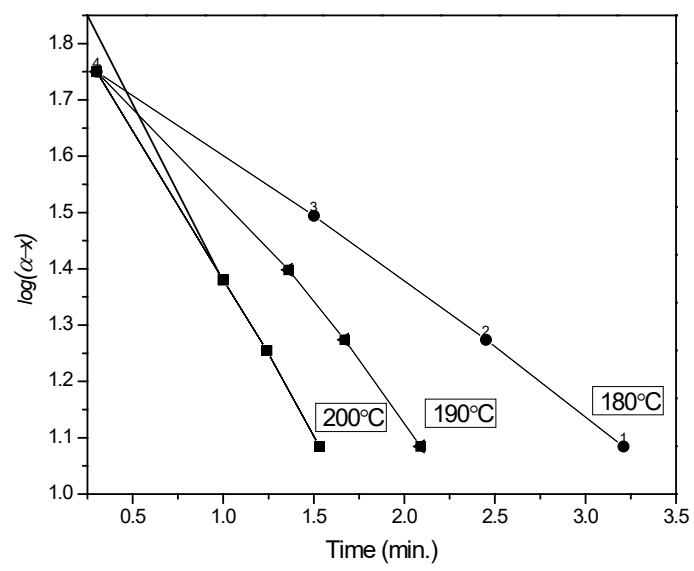

Figure 8. Variation of with time for DCP cured EPDM at $180^{\circ} \mathrm{C}$, $190^{\circ} \mathrm{C}, 200^{\circ} \mathrm{C}, \operatorname{mix} \mathrm{A}_{1}$

The half-life, the time required for half of the peroxide in the formulation to thermally decompose decreases with the increased temperature. Half-lives completed at $t_{90}, t_{95}, t_{100}$ are also given in Tables 8, 9 and 10.

Table 8. Variation of the rate constant and $t_{1 / 2}$ completed halflife with temperature ( $\left.\operatorname{mix} \mathrm{A}_{3}\right)$

\begin{tabular}{ccccccc}
\hline $\begin{array}{c}\text { Temperature } \\
{ }^{\circ} \mathrm{C}\end{array}$ & $\begin{array}{c}t_{1 / 2} \\
\mathrm{~min}^{-1}\end{array}$ & $\begin{array}{c}k \\
\mathrm{~min}^{-1}\end{array}$ & $\begin{array}{c}t_{90} \\
\min \end{array}$ & $\begin{array}{c}t_{95} \\
\min \end{array}$ & $\begin{array}{c}t_{100} \\
\text { min }\end{array}$ & $\begin{array}{c}t s_{2} \\
\text { min }\end{array}$ \\
\hline 180 & 2.57 & 0.2689 & 1.27 & 2.07 & 3.89 & 0.9 \\
190 & 1.59 & 0.4340 & 0.78 & 1.35 & 2.77 & 0.5 \\
200 & 0.83 & 0.8380 & 0.57 & 1.28 & 2.76 & 0.4 \\
\hline
\end{tabular}

Table 9. Variation of the rate constant and $t_{1 / 2}$ completed halflife with temperature $\left(\operatorname{mix} A_{2}\right)$

\begin{tabular}{ccccccc}
\hline $\begin{array}{c}\text { Temperature } \\
{ }^{\circ} \mathrm{C}\end{array}$ & $\begin{array}{c}t_{1 / 2} \\
\mathrm{~min}^{-1}\end{array}$ & $\begin{array}{c}k \\
\mathrm{~min}^{-1}\end{array}$ & $\begin{array}{c}t_{90} \\
\text { min }\end{array}$ & $\begin{array}{c}t_{95} \\
\text { min }\end{array}$ & $\begin{array}{c}t_{100} \\
\text { min }\end{array}$ & $\begin{array}{c}t s_{2} \\
\text { min }\end{array}$ \\
\hline 180 & 8.20 & 0.0845 & 1.00 & 1.71 & 2.92 & 0.8 \\
190 & 4.57 & 0.1514 & 0.73 & 0.97 & 1.82 & 0.6 \\
200 & 3.62 & 0.1912 & 0.6 & 0.84 & 1.23 & 0.5 \\
\hline
\end{tabular}

Table 10. Variation of the rate constant and $t_{1 / 2}$ completed halflife with temperature $\left(\operatorname{mix} A_{1}\right)$

\begin{tabular}{ccccccc}
\hline $\begin{array}{c}\text { Temperature } \\
{ }^{\circ} \mathrm{C}\end{array}$ & $\begin{array}{c}t_{1 / 2} \\
\mathrm{~min}^{-1}\end{array}$ & $\begin{array}{c}k \\
\mathrm{~min}^{-1}\end{array}$ & $\begin{array}{c}t_{90} \\
\mathrm{~min}\end{array}$ & $\begin{array}{c}t_{95} \\
\mathrm{~min}\end{array}$ & $\begin{array}{c}t_{100} \\
\mathrm{~min}\end{array}$ & $\begin{array}{c}t s_{2} \\
\mathrm{~min}\end{array}$ \\
\hline 180 & 5.08 & 0.2364 & 0.84 & 1.04 & 2.16 & 0.8 \\
190 & 3.39 & 0.2036 & 0.73 & 0.92 & 1.47 & 0.5 \\
200 & 3.26 & 0.2128 & 0.45 & 0.64 & 0.92 & 0.5 \\
\hline
\end{tabular}

After the first half-life, $87.2 \%$ of DCP, $87.1 \%$ DBTPIB and $87.5 \%$ of DTBPH decompose. The process continues and theoretically never reaches $100 \%$ of decomposition/consumption. After two half-lives $97.5 \%$ DCP, 93.6\% of DTBPIB and $98.2 \%$ of DTBPH decompose. It is to be noted that $\mathrm{t}_{100}$ for DCP, DTBPIB, and DTBPH accounts for an average of 2 to 3 half-lives. Figure 9 shows the effect of temperature on the cure rate index (CRI) and delta torque. The torque differences of peroxide DCP extend significantly more with the cure temperature than those of other compounds (Figure 8). For DCP at $180^{\circ} \mathrm{C}$, the cure rate index $(\mathrm{CRI})$ which indicates the efficiency of peroxide is the same as for DTBPIB at $190{ }^{\circ} \mathrm{C}$, while for peroxide DTBPH the values of $\mathrm{CRI}$ were two times higher than for other two peroxides at $180^{\circ} \mathrm{C}$. Cure times (tc90) in EPDM were compared in Figure 10. It can be seen that cure time decreases with increasing the temperature. Peroxide DTBPH has a slow curing time up to 9 min. at $180{ }^{\circ} \mathrm{C}$ and dramatical values of curing times decrease 3 times at $190^{\circ} \mathrm{C}$ and $200^{\circ} \mathrm{C}$. Peroxides DCP and DTBPIB clearly had fast cure times which indicates that DBTPH could achieve faster curing: about 3 times faster than other peroxides at $180^{\circ} \mathrm{C}$ and about 2 times faster by increasing the cure temperature up to $10^{\circ} \mathrm{C}$. This could be one of the reasons to use DTBPH at curing temperatures lower than $180^{\circ} \mathrm{C}$ in order to avoid thermal degradation, while the other peroxides cannot reach the same cure level below $180^{\circ} \mathrm{C}$. Figure 9 shows the cure rate index $(\mathrm{CRI})$ where the efficiency of DCP at $180^{\circ} \mathrm{C}$ is the same as DBTPIB at $190^{\circ} \mathrm{C}$.

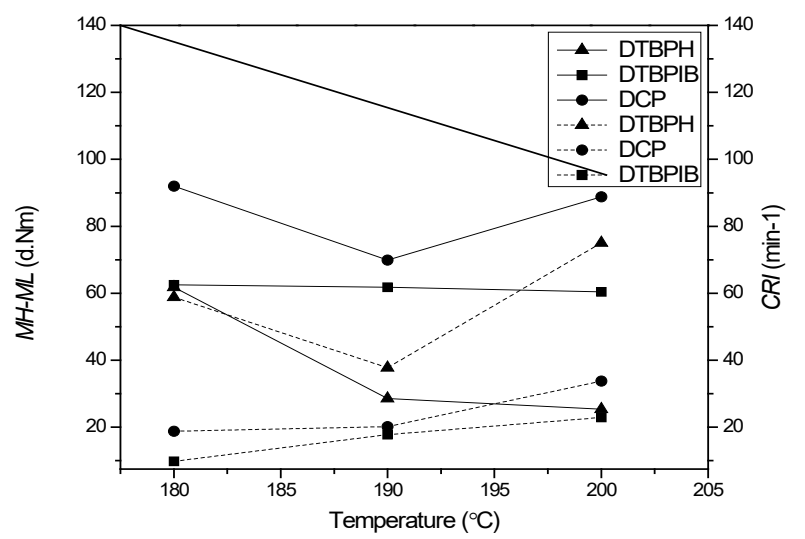

Figure 9. Effect of temperature on tourqe differences $(-\mathrm{MH}-$ $M L)$ and the index of the cure rate (--CRI) of (mix $\left.A_{1}, A_{2}, A_{3}\right)$ 


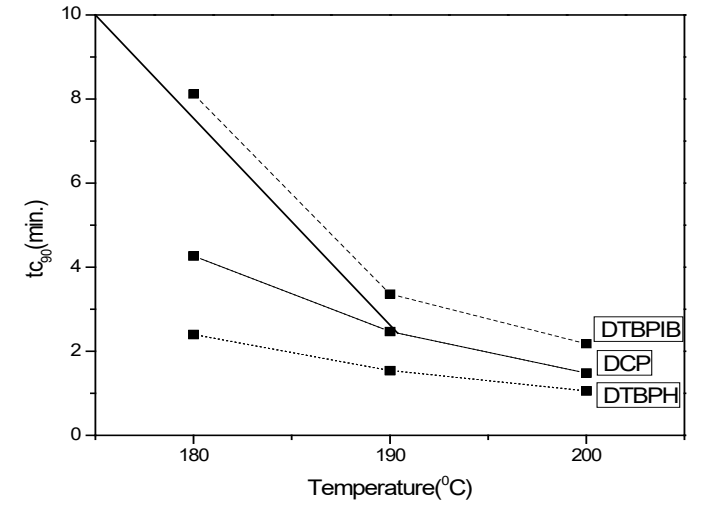

Figure 10. Effect of curing temperature on tc90 of (mix $\left.A_{1}, A_{2}, A_{3}\right)$

\section{Mechanical properties}

The variation of the tensile strength with the concentration of peroxide and the content of ethylene in EPDM is shown in Figure 11. The tensile strength increased with the increase of the concentration of peroxide up to an optimum level and then decreased, but in EPDM with $59 \%$ of ethylene, the tensile strength stays much more constant at all peroxides when the optimum concentration is reached. At peroxide DTBPIB crosslinked with EPDM ( ethylene content $45 \%$ and $75 \%$ ) the values of the tensile strength at the concentration of $10 \mathrm{phr}$ and at higher concentrations were almost the same. Opposite to these trends, after the treatment with peroxide DCP, the values of the tensile strength were the same at the concentration of $10 \mathrm{phr}$ in EPDM (with the ethylene content $45 \%$ and $75 \%$ ) but at higher concentration values of the tensile strength they decreased. This could be attributed to the fact that at the higher peroxide level, there is the increase in the amount of residual peroxide, as well as the possibility of the formation of clusters due to the non-homogeneous distribution of crosslinks [14, 15]. It can be seen from Figure 12 that the value of the tensile strength of peroxide DTBPH at the concentration of $12.5 \mathrm{phr}$ is the highest with the ethylene content of $45 \%$, even higher than the tensile strenght of peroxide DCP and DTBPIB at the same concentration (12.5 phr) and with $75 \%$ of the ethylene content in EPDM.

It can be seen from Figure 12 that elongation at break increases with increasing the concentration of peroxide up to an optimum level (10 phr), and then decreased with increasing the concentration of peroxide. Opposite to this trend, the values of elongation at break decreases with increasing the content of ethylene in EPDM, which is not the case with peroxide DCP where the content of ethylene does not influence the values of elongation at break. The values of elongation at break of peroxide DTBPH are the highest with the concentration of $10 \mathrm{phr}$ and the ethylene content of $45 \%$. Even at the lower concentration of peroxide DTBPH, the value of elongation at break was the highest.

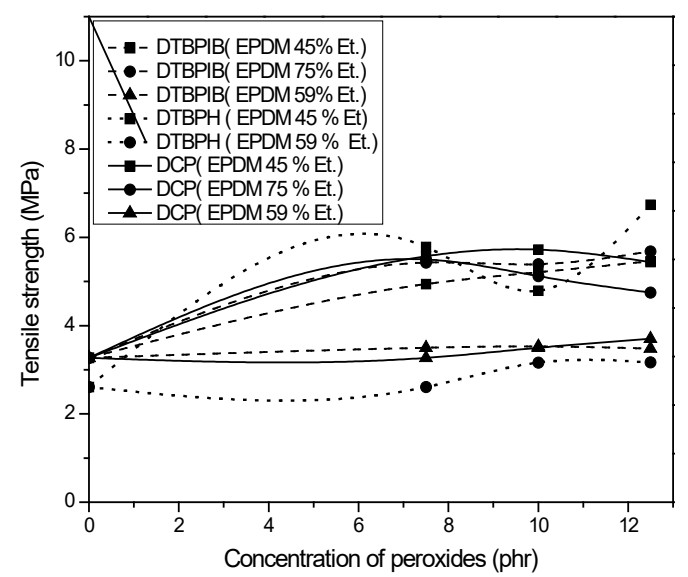

Figure 11. Variation of the tensile strength as a function of the concentration of peroxides and the ethylene content in EPDM

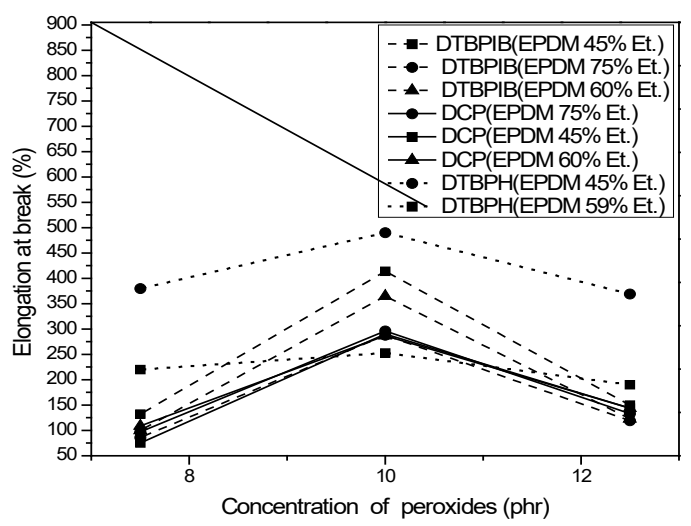

Figure 12. Variation of elongation at break as a function of the concentration and type of peroxides and the ethylene content in EPDM

\section{Conclusions}

Considering the fact that peroxide vulcanization of EPDM is one of the most widely used methods in the cable industry, the producers in the world are trying to achieve better production while they are dealing with different factors that will influence the final properties of the product. In this study three most common peroxides and their influence on properties of EPDM with various contents of ethylene were used. It was found that Peroxide DCP is good for curing at temperatures in the range of $180{ }^{\circ} \mathrm{C}$ to $190{ }^{\circ} \mathrm{C}$ which accomplished an ultimate cure within 11 to 5 minutes. More over, DTBPH has higher performance, which decreased the optimum cure time to 1.5 minutes. Peroxide DBTPH could achieve faster curing: about 3 times faster than other peroxides at $180^{\circ} \mathrm{C}$ and about 2 times faster by increasing the cure temperature up to $10{ }^{\circ} \mathrm{C}$. The crosslinking efficiency of peroxide depends on the number of completed half-lives. In order to avoid thermal degradation, peroxide could be used at 
temperatures lower than $180^{\circ} \mathrm{C}$. While other peroxides cannot reach the same cure level below $180{ }^{\circ} \mathrm{C}$. After two half-lives decompose $97.5 \%$ DCP, $93.6 \%$ of DTBPIB and $98.2 \%$ of DTBPH is decomposed. Besides the peroxide concentration which is the dominant factor at the temperatures lower than $180^{\circ} \mathrm{C}$, the important factor for peroxide vulcanization is also the content of ethylene in EPDM. The values of elongation at break and the tensile strength of peroxide DTBPH is the highest with the concentration of $7.5 \mathrm{phr}$ and the ethylene content of $45 \%$. DCP and DTBPIB peroxides show excellent mechanical properties at the concentration of $10 \mathrm{phr}$ and with EPDM which consists of $45 \%$ of ethylene. The interplay between key variables in the formulation was important for evaluating final mechanical properties of the final product, in this case, a medium voltage cable.

\section{References}

[1] F. P. Baldwin, G. Ver Strate, Polyolefin elastomers based on ethylene and propylene rubber, Rubber Chemistry and Technology., 45 (3) (1972 ) 709-881.

[2] I. D. Rosca, J. M. Vergnaud, Study of process of cure of EPDM rubber in moving die rheometer, Plastic, Rubber and Composites: Macromolecular Engineering. 30 (6) (2001) 275-281.

[3] P.R. Dluzenski, Peroxide vulcanization of elastomers, Rubber Chem. Technol., 74 (3)(2001) 451-492.

[4] W. Hoffman, Rubber Technol.Handbook, Hanser Publishers, New York (1994)
[5] R.C Keller,Peroxide curing of ethylene-propylena elastomers Rubber Chem. Technol., 61(2)(1988) 238-254

[6] L.D Loan, Peroxide crosslinking of ethylene propylene rubber, J.Polym. Sci.A, 2 (7) (1964) 3053-3066.

[7] D.S Ogunniyi, Peroxide vulcanization of rubber Prog. Rubber Plast.Technol., 15 (1999) 95.

[8] M. Braden, W.P Fletcher, G.P McSweeny, Trans.Inst Rubber Tnd. 30(44)

[9] WC.Endstra, Proceedings of the SRC'85 conference on "Organic peroxides for crosslinking applications"., (1985).

[10] D.W Brazier, N.V Schwartz, The cure of elastomers by dicumyl peroxide as observed in differential scanning calorimetry, Thermochimica Acta, 39(1) (1980) 7-20.

[11] K.Nasakar, Dynamically vulcanized PP/EPDM thermoplastic elastomers:exploring novel routes for crosslinking with peroxides, Phd Thesis, Unyversity of Twente, Netherlands, (2004).

[12] EN ISO 6502: Rubber measurement of vulcanization characteristics with rotorless curemeters. 1991.

[13] K. C Baranwal, H. L Stephenes, Basic Elastomer Technology. Rubber Division, American Chemical Society Akron 1, (2001).

[14] L. Gonzales, A. Rodrigez, A. Marcos, C. Chamorro, Crosslink Reaction of Diene Rubber with Dicumyl Peroxide, Rubber Chemistry and Technology. 69 (2) (1996) 203-214.

[15] J. L Valentin, P. Posadas, A. Fernandez-Torres, M. A Malmierca, L. Gonzales, W. Chasse, K. Saalwachter, Inhomogeneites and chain dynamics in Diene Rubbers vulcanized with different cure systems. Macromolecules, 43 (2010) 4210-4222.

\section{Izvod \\ UTICAJ PEROKSIDA NA PROCES UMREŽAVANJA EPDM IZOLACIJE KABLOVA SREDNJEG NAPONA}

Jelena Radosavljević, Ljubiša Nikolić

Tehnološki fakulet, Univerzitet u Nišu, Leskovac, Srbija

Ovaj rad opisuje uticaj koncentracije i vrste peroksida na efikasnost umrežavanja različitih tipova EPDM-a (etilen propilen dien monomer (M-klase) gumu), [1] [2] [10] sa različitim sadržajem etilena koji se koristi u širokom spektru aplikacija. Reološke karakteristike su ispitane korisćenjem Monsanto reometra sa temperaturnim režimom u opsegu između 180 i $200{ }^{\circ} \mathrm{C}$, gde se mere parametri reometarskih krivi na svakih $10^{\circ} \mathrm{C}$. Mehaničke osobine: zatezna čvrstoća i prekidno izduženje su ispitani sa testom zatezanja u skladu sa standardom ASTM D-412. Dobijeni rezultati ukazuju da peroksid DTBPH sa koncentracijom 7.5 phr daje najbolje rezultate (vreme umrežavanja $1,5 \mathrm{~min}$.) na temperaturi od 180 do $190^{\circ} \mathrm{C}$. Pri većoj koncentraciji peroksida, prilikom umrežavanja ostaje veća količina rezidvalnog peroksida, koji povećava mogućnost preumrežavanja i nastajanja nehomogene umrežene strukture. Peroksidno umreženi EPDM sa $45 \%$ sadržaja etilena daje najefikasnije mehaničke osobine izolacije srednje naponskih kablova. Značajno je pomenuti da vreme koje je potrebno za potpuno $100 \%$ umrežavnje EPDM-a (t100) za perokside dikumil peroksid (DCP), di (tert-butil peroksi izopropil) benzen (DTBPIB), and (2.5-di metil-2.5-di (tert-butilperoksi) heksan (DTBPH) u proseku odgovara za 2-3 njihova poluvremena raspada.
(ORIGINALNI NAUČNI RAD) UDK 678.7:66.095.26:665.94

Ključne reči: Umrežavanje, kinetika, EPDM, organski peroksid, reološke karakteristike. 